\title{
Influence of Variety and Sulfite on Controlling Browning Within Four Months of Storage of Dehydrated Jackfruit (Artocarpus heterophyllus Lam.) Pulp
}

\author{
Lorina A. Galvez ${ }^{1}$, Remberto A. Patindol ${ }^{2}$ \\ and Linda B. Mabesa ${ }^{3}$
}

\begin{abstract}
${ }^{1}$ Department of Food Science and Technology, College of Agriculture and Food Science, Visayas State University, Visca, Baybay City, Leyte,6521, Philippines, ${ }^{2}$ Department of Mathematics, Physics and Statistics, College of Arts and Sciences, Visayas State University, Visca, Baybay City, Leyte,6521, Philippines, ${ }^{3}$ Institute of Food Science and Technology, College of Agriculture, University of the Philippines Los Baños, Laguna Philippines,
\end{abstract}

\begin{abstract}
The main problem of the dehydrated jackfruit developed by the Visayas State University (VSU) is that it develops browning after one to two months even if the product is packed in a good packaging material. This study was conducted to determine the effects of variety and sulfite in controlling browning within 4 months of storage of dehydrated jackfruit pulp. Two recommended jackfruit varieties (AES Jak 1 and AES Jak 2 ) and two levels of sulfite $(0.1$ and $0.2 \% \mathrm{w} / \mathrm{w}$ ) were used in the study. Treatments were laid out in CRD with three replications. Data were analyzed using SPSS version 16 and HSD was used to test the significance between treatments. Different parameters on physico-chemical properties and functional components of the product were investigated at 0,2 and 4 months of storage.

Results revealed that utilization of AES Jak 1 variety and either 0.1 or $0.2 \%$ $\mathrm{w} / \mathrm{w}$ sulfite can be used in dehydrated jackfruit processing with least browning during storage. Correlation analysis showed that as $\mathrm{pH}$ and TTA increase, DB decreases which indicates that $\mathrm{pH}$ and TTA can be used as control in minimizing browning. The weak correlation of TP and TC on DB implies that browning of stored dehydrated jackfruit is caused by non-enzymatic reaction.
\end{abstract}

Keywords: Physico-chemical properties, dehydrated jackfruit, functional components.

Correspondence : L.A. Galvez. Address: Department of Food Science and Technology, Visayas State University, Visca, Baybay City, Leyte, Philippines 6521-A. Tel. No: (053)335-2619. E-mail: galvez3352@yahoo.com

DOI: $10.32945 / \operatorname{atr} 3523.2013$ 


\section{INTRODUCTION}

Jackfruit is a delicious tropical composite fruit with succulent and firmly textured bulbs. Widely grown in the Philippines, it is one of the tropical fruits which produce the largest edible fruit that may weigh as much as $50 \mathrm{~kg}$ (Coronel, 1983).The fruit deteriorates rapidly upon ripening like other climacteric fruits. In the Philippines, specifically in the Visayas areas (Western, Central and Eastern Visayas), jackfruit is one of the priority commodities wherein almost half of the total land area is allotted to jackfruit production (Cruz, 2002). More efforts were done for the identification and propagation of promising jackfruit accessions to increase jackfruit production in the region. Two jackfruit varieties were identified and recommended for food processing by the Department of Agriculture. They are AES Jak 1 (EVIARC sweet) and AES Jak 2.

With the increasing volume of production especially on these two varieties, processing technologies that have high commercial viability are required so that more Filipino jackfruit products can be expected in the local or high end market which usually relies on the processed products. This can help increase the earning of our country and alleviate our economy. It was even reported by the Animal Husbandry and Agricultural Journal (1995) as cited by Cruz (2002) that the Philippines' export earnings from jackfruit averaged about half a million dollars $(\$ 500,000)$ annually.

Jackfruit has a high potential for processing into high-valued food products because of its unique aroma and flavor. One of the processing techniques that can increase its commercial value is through dehydration process.

Visayas State University (VSU) in Baybay City, Leyte, Philippines had developed a technology on dehydrated jackfruit to diversify the utilization of jackfruit, to increase its commercial viability and to avoid wastage of the crop (Diamante, 2005). At the start of the research, sulfite was used as preservative ( Pesquera, 2002; Sansan, 2004 and Fernandez, 2005) since sodium sulphite is a potent inhibitor of polyophenol oxidases and peroxidases and is used widely used to inhibit enzymatic and nonenzymatic browning in fruits and vegetables (Wu et al.,1999; Molnar-Perl \&Friedman,1990 as cited in Singh et al.,2002, Brown, 2005; and Johnton and Bahr, 1995 ). To enhance the color, texture, and flavor of the dehydrated jackfruit, sulfite can be added into the syrup used in dehydration (De Leon, 1987). Lucban (1983) found that jackfruit bulbs immersed in $0.1 \%$ sodium metabisulfite prior to dehydration and those which were steam blanched 
for three minutes then immersed in $0.1 \%$ sodium metabisulfite did not differ significantly in terms of sensory qualities. In addition, Lambrecht (1995) mentioned that sulfites react with PPO itself, thus irreversibly inhibiting PPO by modification of the protein structure. However, because of the adverse effects of sulfite on the health of the consumers following ingestion of sulfite treated food products by hypersensitive asthmatics (Marshall et al., 2000), the researcher thought of coming up with another research using citric acid and ascorbic acid as preservatives (Golosino, 2004; Tambis, 2006 and Lapiceros, 2007) with the purpose of increasing shelf life of the product and making it safer considering the health drawbacks associated with the use of sulfite. However, it was found that during the commercialization process, browning still occurred after one to two months even if the product was contained in a good packaging material. This problem needs to be addressed to increase the commerciability of the product.

Browning reactions in food are widespread phenomena which take place during processing and storage. These reactions occur during the manufacture of meat, fish, fruit and vegetable products, as well as when fresh fruits and vegetables are subjected to mechanical injury. It affects the flavor, appearance, and nutritive value of the food products involved (Eskin, 1990). Browning reactions during processing and storage of foods are responsible for the deterioration of food product and profit losses among food processors (Lambrecht, 1995). There are four major types of browning in foods: Maillard, caramelization, ascorbic acid oxidation and phenolase or enzymatic browning (Lambrecht, 1995).

Enzymatic browning of fruit is a well-known phenomenon caused by the oxidation of phenolic compounds into quinones (Nicolas et al., 1994). This is mainly catalyzed by polyphenol oxidase in the presence of oxygen (Lee and Whitaker, 1995) and gives rise to a brown pigmentation. This brown discoloration leads to organoleptic and nutritional modifications in the plant tissues, thus causing unfavorable quality changes in the food products (Carbonara and Mattera, 2001).This occurs usually when the tissue is bruised, cut, peeled, diseased or exposed to any abnormal conditions (Eskin, 1990). Non-enzymatic browning (Maillard reaction) is a result of reducing compounds, primarily sugars, reacting with proteins or free amine groups. This changes both the chemical and the physiological properties of protein. In general, the accumulation of brown pigment is the most obvious indication if Maillard browning has occurred in a food containing both carbohydrates and protein (Rahman and Labuza, 2007). 
Among the important product affected by maillard browning during its processing and storage is the dehydrated fruit products.

Because of the findings stated above, sulfite as a preservative is a must in the dehydration process of jackfruit; however, minimal concentration should be used to lessen its negative effects on the consumers especially those with asthma. Since we have two jackfruit varieties recommended for processing, probably jackfruit variety should be looked into since it is a known fact that variety affects the quality of the raw material and finished product which could be contributed by the inherent characteristics of the crop. However, there is no published article yet comparing these two varieties in dehydrated jackfruit processing in combination with different sulfite levels on the quality of dehydrated jackfruit during storage which in a way helps in the standardization of procedure on controlling browning in dehydrated jackfruit. Hence, this study was conducted.

\section{MATERIALS AND METHODS}

\section{Raw Materials}

Abuyog Experimental Station AES Jak 1 and AES Jak 2 jackfruit varieties were procured from Jackfruit Planters in Ormoc City and Inopacan, Leyte, respectively. The samples were brought to the Department of Food Science and Technology, VSU, Visca, Baybay City, Leyte for processing and analysis.

\section{Experimental Design}

The different treatments were laid out in completely randomized design (CRD). There were two levels of sulfite with two varieties totaling to 4 treatments.

\section{Dehydration Process}

Jackfruits were washed and rinsed with chlorinated water (100 ppm) and sliced along the lateral axis into halves. The pulp was taken and then deseeded. The pulp was halved and boiled in $75 \%$ (w/w) sugar syrup for 60 $\mathrm{min} / 15 \mathrm{~kg}$ and $35 \mathrm{~min} / 15 \mathrm{~kg}$ (time of doneness) for AES Jak 2 and AES Jak 1 , respectively. These were cooled and added with different amounts of preservatives in each variety as follows: $\mathrm{P}_{1}=0.1 \%$ sulfite $+0.1 \%$ sodium 
benzoate $+0.3 \% \mathrm{w} / \mathrm{w}$ citric acid, and $\mathrm{P}_{2}=0.2 \%$ sulfite, $0.1 \%$ sodium benzoate and $0.3 \% \mathrm{w} / \mathrm{w}$ citric acid based on the weight of pulp. The samples were soaked in syrup concentration for $24 \mathrm{~h}$, drained, and rinsed with boiled and cold water. The drained samples were laid on the trays, then, dried at ambient humidity and at a temperature of $70^{\circ} \mathrm{C}$ for 8 hours, with loading density of $60 \mathrm{~kg} / 8$ trays. The dried samples with 10-12\%MC were allowed to sweat overnight and were packed in a laminated tin foil bag and stored for $4 \mathrm{mo}$. in opaque plastic containers at ambient temperature ready for different analyses.

\section{Physico-chemical and functional analyses}

The four treatments were subjected to storage study namely, T1 (AES Jak 1 and $0.1 \% \mathrm{w} / \mathrm{w}$ sulfite), T2 (AES Jak 1 and $0.2 \% \mathrm{w} / \mathrm{w}$ sulfite),T3 (AES Jak 2 and $0.1 \% \mathrm{w} / \mathrm{w}$ sulfite) and T 4 (AES Jak 2 and $0.2 \% \mathrm{w} / \mathrm{w}$ sulfite). The basis of their selection was based on their degree of browning (DB) value. The packaged dehydrated samples were placed in the big plastic container and samples were drawn every two months and analyzed for the different physico-chemical and functional component analyses. The different physico-chemical analyses include $\mathrm{pH}$, total titratable acidity (TTA) following AOAC (1980), total soluble solids (TSS), moisture content (\%MC) following AOAC (1980), water activity $\left(A_{w}\right)$ (DOST-8, protocol) and DB following the method of Baloch et al. (1973) as cited in Mahayothee et al. (2009) with little modification. The functional components analyses include total phenolics (TP) following protocol of Velioglu et al. (1998), tannin content (TC) following protocol of Sun et al. (1998), total reducing sugars (TRS) DNS assay protocol of Miller (1972), total sulfur (TS) following protocol of Sandhu et al. (1974) and antioxidant activity (AOA) using the procedure of Leong and Shui (2002).The AOA is measured as \% lipid peroxidation (\% LP), where the higher the \%LP the lower is its antioxidant activity. Analysis of the samples was done in triplicate following standard protocols.

\section{Statistical analyses}

The effect of sulfite levels and variety on the physico-chemical and functional data obtained were analyzed by subjecting the data to analysis of variance (ANOVA) at 5\% level of significance employing SPSS 16. The treatment means were compared using HSD (Honestly Significance 
Difference at 5\% level) if significant results were obtained. Pearson correlation analysis was done to evaluate the relationship of each of the parameters to degree of browning (DB).

\section{RESULTS AND DISCUSSION}

\section{Physico-chemical Properties}

$p H$. The results of the combination of variety and sulfite levels with storage time of the different samples are shown in Table 1. Results revealed that at 0,2 and 4 months of storage the sulfite levels had no significant effect on the $\mathrm{pH}$ values of the product for AES Jak 1 (T1 and T2). For AES Jak 2 (T3 and T4) treatments, sulfite levels did not cause a significant effect on the $\mathrm{pH}$ values of the product after 0 and 4 months of storage while significant difference was observed after 2 months of storage. Variety significantly affected the $\mathrm{pH}$ of the sample for both the sulfite levels ( 0.1 or $0.2 \% \mathrm{w} / \mathrm{w}$ ) from 0,2 , and 4 months storage. Generally, the sulfite levels did not cause significant change to the $\mathrm{pH}$ of the product after 0,2 and 4 months storage since sulfite does not contribute to the $\mathrm{H}^{+}$ concentration of the product. According to Brown (2005) $\mathrm{pH}$ is the -log concentration of hydrogen ion. On the other hand, variety affected significantly the $\mathrm{pH}$ of the product either with 0.1 or $0.2 \% \mathrm{w} / \mathrm{w}$ sulfite since the two jackfruit varieties have inherent organic acids present which contributed to the $\mathrm{pH}$ of the samples.

Total titratable acidity (TTA). The mean TTA values of the 4 treatments with storage are shown in Table 1 . Storage study revealed that at 0,2 , and 4 months of storage the sulfite levels $(0.1 \mathrm{or} 0.2 \% \mathrm{w} / \mathrm{w})$ did not cause significant effect on the TTA of the product for both varieties (AES Jak 1 and AES Jak 2). However, the variety for a given sulfite level either 0.1 or $0.2 \% \mathrm{w} / \mathrm{w}$ a significant difference on the TTA values of the product was observed. This result could be explained by the different nature of the two jackfruit varieties with respect to their acidity expressed as percent citric acid. Worth noting that with respect to $\mathrm{pH}$, AES Jak 2 treatment have lower $\mathrm{pH}$ values and with lower TTA values. This means that the AES Jak 2 treatments are more acidic than the AES Jak 1 treatments. While with respect to TTA, AES Jak 2 treatments are less acidic than AES Jak 1. The rule of thumb is the lower the $\mathrm{pH}$, the higher should be the TTA. However, this is just a rule not a law, considering that in this case TTA only measures the total acidity as \% citric acid present in the sample. While $\mathrm{pH}$ measures the concentration of hydrogen ion which includes all the organic acids present in the sample. 
Table 1. Mean ${ }^{1}$ values for $\mathrm{pH}, \mathrm{TTA}, \mathrm{TSS}, \mathrm{MC}, \mathrm{Aw} \& \mathrm{DB}$ of dehydrated jackfruit during 4 months storage at ambient temperature

\begin{tabular}{|c|c|c|c|c|c|c|}
\hline \multirow[t]{2}{*}{ PARAMETER } & \multirow[t]{2}{*}{$\begin{array}{l}\text { TREAT- } \\
\text { MENT }\end{array}$} & \multirow[t]{2}{*}{ VARIETY } & \multirow[t]{2}{*}{$\begin{array}{c}\text { SULFITE } \\
(\% \mathrm{w} / \mathrm{w})\end{array}$} & \multicolumn{3}{|c|}{$\begin{array}{c}\text { STORAGE } \\
(\text { mos. })\end{array}$} \\
\hline & & & & 0 & 2 & 4 \\
\hline \multirow[t]{4}{*}{$\overline{\mathrm{pH}}$} & T1 & AES Jak 1 & 0.1 & $4.63 a$ & $4.73 a$ & $4.63 a$ \\
\hline & $\mathrm{T} 2$ & & 0.2 & $4.60 a$ & $4.70 a$ & $4.63 a$ \\
\hline & $\mathrm{T} 3$ & AES Jak 2 & 0.1 & $4.50 b$ & $4.60 b$ & $4.50 b$ \\
\hline & $\mathrm{T} 4$ & & 0.2 & $4.50 b$ & $4.50 c$ & $4.50 b$ \\
\hline Total Titratable & $\mathrm{T} 1$ & AES Jak 1 & 0.1 & $0.36 a$ & $0.44 a$ & $0.36 a$ \\
\hline Acidity (TTA, $\%$ & $\mathrm{~T} 2$ & & 0.2 & $0.36 a$ & $0.40 a$ & $0.36 a$ \\
\hline \multirow{2}{*}{ citric acid) } & T3 & AES Jak 2 & 0.1 & $0.30 b$ & $0.30 b$ & $0.32 b$ \\
\hline & T4 & & 0.2 & $0.29 b$ & $0.31 b$ & $0.32 b$ \\
\hline Total Soluble Solids & $\mathrm{T} 1$ & AES Jak 1 & 0.1 & $68.60 b$ & $78.80 a$ & $76.60 b$ \\
\hline \multirow[t]{3}{*}{ (TSS, ${ }^{\circ}$ Brix) } & $\mathrm{T} 2$ & & 0.2 & $75.20 a$ & $80.80 \mathrm{a}$ & $79.80 a b$ \\
\hline & T3 & AES Jak 2 & 0.1 & $76.60 a$ & $74.60 b$ & $83.50 a$ \\
\hline & $\mathrm{T} 4$ & & 0.2 & $75.80 a$ & $75.10 b$ & $82.60 a$ \\
\hline MC (Moisture & $\mathrm{T} 1$ & AES Jak 1 & 0.1 & $12.04 a$ & $14.64 a$ & $12.95 a$ \\
\hline \multirow{3}{*}{ Content, $\%, w b)$} & $\mathrm{T} 2$ & & 0.2 & $10.88 a$ & $14.95 a$ & $13.58 a$ \\
\hline & T3 & AES Jak 2 & 0.1 & $11.15 a$ & $13.45 b$ & $13.04 a$ \\
\hline & $\mathrm{T} 4$ & & 0.2 & $10.61 a$ & $13.59 b$ & $12.64 a$ \\
\hline \multirow{4}{*}{$\mathrm{A}_{\mathrm{w}}$ (Water Activity) } & $\mathrm{T} 1$ & AES Jak 1 & 0.1 & $0.80 b$ & $0.82 b$ & $0.76 b$ \\
\hline & $\mathrm{T} 2$ & & 0.2 & $0.81 \mathrm{a}$ & $0.82 b$ & $0.77 a b$ \\
\hline & T3 & AES Jak 2 & 0.1 & $0.79 b$ & $0.83 a$ & $0.78 a$ \\
\hline & $\mathrm{T} 4$ & & 0.2 & $0.78 c$ & $0.83 a$ & $0.78 a$ \\
\hline \multirow{4}{*}{$\begin{array}{l}\text { DB(Degree } \\
\text { Browning) }\end{array}$} & $\mathrm{T} 1$ & AES Jak 1 & 0.1 & $0.033 a b$ & $0.013 c$ & $0.021 b$ \\
\hline & $\mathrm{T} 2$ & & 0.2 & $0.029 b$ & $0.006 d$ & $0.025 b$ \\
\hline & $\mathrm{T} 3$ & AES Jak 2 & 0.1 & $0.043 a$ & $0.056 b$ & $0.032 a$ \\
\hline & $\mathrm{T} 4$ & & 0.2 & $0.038 a b$ & $0.063 a$ & $0.035 a$ \\
\hline
\end{tabular}

${ }^{1} \mathrm{~N}=3$. Means in the same column with same letters are not significantly $(P \leq 0.05)$ different with each other.T1 (AES Jak 1, 0.1\%w/w sulfite), T2 (AES Jak 1,0.2\%w/w sulfite), T3 (AES Jak 2, $0.1 \% \mathrm{w} / \mathrm{w}$ sulfite) and T4 ( AES Jak $2,0.2 \% \mathrm{w} / \mathrm{w}$ sulfite).

Total soluble solids (TSS). The effect of storage on TSS values is shown in Table 1. At 0 month of storage, the TSS values of AES Jak 1 treatments (T1 and T2) were significantly affected by sulfite levels while there was no significant difference for AES Jak 2 treatments (T3 and T4). Variety significantly affected the TSS at lower sulfite level $(0.1 \% \mathrm{w} / \mathrm{w})$ and no significant difference was noted at higher sulfite level $(0.2 \% \mathrm{w} / \mathrm{w})$. After 2 months of storage, sulfite levels did not cause a significant difference on the TSS values of AES Jak 1 treatments (T1, T2) and AES Jak 2 ( T3 and T4) treatments. Moreover, variety significantly affected the TSS values either with $0.1 \%$ or $0.2 \% \mathrm{w} / \mathrm{w}$ of sulfite level. At 4 months of storage, sulfite levels did not cause significant change on the TSS of the product for AES Jak 1 and AES Jak 2 treatments. Variety caused significant change of TSS at lower sulfite level where T3 (AES Jak 2) has higher TSS value than T1 (AES Jak 1). 
This result could be attributed to the difference of the inherent TSS of each variety.

Moisture content (\%MC). Water removal was the main task while preserving food (Lenart, 1996); hence, reducing the moisture contents to a level that allowed safe storage over an extended period of time (Okos et $a l, 1992$ as cited in Fernandes et al. 2006).The change in \%MC values is shown in Table 1. The MC of the four treatments (T1, T2, T3 and T4) were not significantly affected by sulfite levels $(0.1$ and $0.2 \% \mathrm{w} / \mathrm{w})$ and variety (AES Jak 1 and AES Jak 2) after 0 and 4 months of storage. However, at 2 months storage, results showed that sulfite levels did not cause a significant effect on the MC of the different treatments. Variety significantly affected the $\mathrm{MC}$ for a given sulfite level, where at higher sulfite level there was a significantly lower MC than at lower sulfite level at a given variety. This result could be attributed to the effect of sulfites on the rupturing the cells, resulting in a smaller cell volume and hardness of the dried samples (Moyls,1981 and Prestamo and Fuster,1984 all cited by Rahman and Perera 2007. In addition, Mcfeeters et al. (2004) reported that sulfite prevents rapid softening in red blue peppers which is directly related to moisture.

Water activity $\left(A_{w}\right)$. The changes in the $\mathrm{A}_{\mathrm{w}}$ values with storage are shown in Table 1. At 0 month storage, sulfite levels caused significant difference on the $A_{w}$ values for AES Jak 1 and AES Jak 2 treatments. For AES Jak 1 variety, $\mathrm{T} 1$ which had $0.1 \%$ sulfite had significantly higher $\mathrm{A}_{\mathrm{w}}$ value than $\mathrm{T} 2$ $(0.2 \% \mathrm{w} / \mathrm{w})$. While the opposite is happening for AES Jak 2 variety. This result could be attributed to the longer heating of AES Jak 2 treatments which was affected by the nature of each variety. AES Jak 1 was cooked or boiled in shorter time considering that the doneness of the samples was reached in a shorter time; however, for the AES Jak 2 variety, longer time of heating or boiling was needed to reach doneness stage. Variety did not affect significantly the $A_{w}$ values at lower sulfite level; however, at higher sulfite level, significant difference of the values was observed. After 2 months and 4 months storage, the effect of sulfite levels and variety were the same where, sulfite levels did not cause significant variation to the $A_{w}$ values while variety at lower sulfite caused significant effect on the $A_{w}$ values. On the other hand, only at higher sulfite level $(0.2 \%)$ after four months where no significant difference was observed on the $A_{w}$ values. Rahman and Labuza (2007) reported that $A_{w}$ of a medium was not the only determining factor regulating microbial response. The nature of the solutes used also played an important role. Intermediate moisture food had lower $A_{w}$ values which were achieved by withdrawal of water by 
desorption, adsorption and or the addition of permissible additives, characterized not only by $A_{w}$ values of $0.60-0.85$ but also by the use of additives such as glycrol, glycols, sorbitol, sucrose, as humectants and by their content of fungistats such as sorbate, benzoate (Jay, 2000) and sulfite.

Degree of browning (DB). The degree of browning was often used analytically to assess the extent to which the Maillard reaction had taken place in foods (Cernisev, 2010). Ahmed et al. (2010) cited Zhang et al. (2005) that browning appeared to be a complex process involving several factors including substrate levels, enzymatic activity, presence of ascorbic acid, and other inhibitors and promoters influencing the browning reaction in addition to tissue damage. The changes of DB of the four treatments are shown in Table 1 . Results revealed that at 0 month storage, sulfite levels did not cause a significant variation on the $D B$ values of each variety. On the other hand, for the variety at a given sulfite level (either 0.1 or $0.2 \% \mathrm{w} / \mathrm{w}$ ), no significant difference of DB values was observed on the product for both varieties. After 2 months of storage, sulfite levels were found to cause significant difference on the DB values for AES Jak 1 and AES Jak 2 treatments. Variety on the other hand significantly influenced the DB values for both sulfite levels, however, worth noting here was a that there is higher DB value for T4 despite higher sulfite level. The difference in DB values might be due to the difference in the concentration of endogenous phenolic compounds inherent in each cultivar (Ding et al.,1998 as cited in Ding et al., 2002). The effective sulfite concentration for preventing discoloration primarily depended on the nature of the available substrate, and that more complex phenolic compounds would require higher sulfite concentration (Ashie et al. 1996 as cited in Quinde-Axtell et al. 2006).

Finally after 4 months of storage, sulfite levels did not cause a significant difference on the DB values for both varieties, while variety was found to cause significant effect on the DB values either at $0.1 \%$ or $0.2 \%$ $\mathrm{w} / \mathrm{w}$. According to Cernisev (2010) the rate, extent and route of Maillard reaction depended on product (composition and quantitative ratio of interacting compounds, $\mathrm{pH}$, moisture) and processing parameters (temperature, and time of its application). The two jackfruit varieties were expected to behave differently when treated and processed since they have different nature and chemical composition.

\section{Functional Properties}

Total phenolics (TP). The changes of the TP values with time are shown in Table 2. Results showed that at 0 month storage, sulfite levels caused 
significant change on the AES Jak 1 treatments but not with AES Jak 2 treatments. Meanwhile variety caused a significant difference of the TP at lower sulfite level $(0.1 \% \mathrm{w} / \mathrm{w})$ only, not with high sulfite level $(0.2 \% \mathrm{w} / \mathrm{w})$. After 2 months of storage, both the sulfite levels did not influence the TP for both varieties and variety did not cause a significant change on the TP values for both sulfite levels. This will just show that after 2 months of storage the different treatments were stable since no significant changes are happening. However, after 4 months of storage, the sulfite levels caused a significant difference on TP values only with AES Jak 2 treatments but not with AES Jak 1 treatments. Variety however, caused no significant difference on TP values either with lower or higher sulfite level.

Table 2. Mean ${ }^{1}$ values for TP, TC, AOA,TRS and TS of dehydrated jackfruit during 4 months storage at room temperature

\begin{tabular}{lcccccc}
\hline PARAMETER & $\begin{array}{c}\text { TREAT- } \\
\text { MENT }\end{array}$ & VARIETY & $\begin{array}{c}\text { SULFITE } \\
(\% \mathrm{w} / \mathrm{w})\end{array}$ & \multicolumn{3}{c}{$\begin{array}{c}\text { STORAGE } \\
(\mathrm{mos} .)\end{array}$} \\
& & & & 0 & 2 & 4 \\
\hline TP (Total & T1 & AES Jak 1 & 0.1 & $28.27 \mathrm{a}$ & $30.12 a$ & $31.96 a b$ \\
Phenolics, mg & T2 & & 0.2 & $25.07 b$ & $27.15 \mathrm{a} b$ & $29.87 \mathrm{bc}$ \\
CE/100g sample) & T3 & AES Jak 2 & 0.1 & $23.63 b$ & $28.59 \mathrm{a} b$ & $32.12 a$ \\
& T4 & & 0.2 & $23.39 b$ & $26.19 b$ & $28.27 c$ \\
TC (Tannin & T1 & AES Jak 1 & 0.1 & $5.98 c$ & $94.66 a$ & $97.03 a$ \\
Content, mg & T2 & & 0.2 & $4.61 c$ & $80.75 \mathrm{~b}$ & $82.62 b$ \\
VE/100g sample) & T3 & AES Jak 2 & 0.1 & $99.67 a$ & $96.82 a$ & $96.58 a$ \\
& T4 & & 0.2 & $84.11 b$ & $83.86 b$ & $86.36 b$ \\
AOA (Antioxidant & T1 & AES Jak 1 & 0.1 & $66.91 \mathrm{cb}$ & $79.24 a$ & $85.42 a$ \\
Activity, \% LP) & T2 & & 0.2 & $63.16 \mathrm{c}$ & $79.48 a$ & $84.94 a$ \\
& T3 & AES Jak 2 & 0.1 & $82.79 a$ & $82.38 a$ & $85.01 a$ \\
& T4 & & 0.2 & $72.20 b$ & $84.07 a$ & $87.31 a$ \\
TRS (Total & T1 & TES Jak 1 & 0.1 & $2.68 c$ & $3.08 c$ & $3.14 b$ \\
Reducing Sugar, \%) & T3 & AES Jak 2 & 0.2 & $2.85 b$ & $3.78 a$ & $3.86 a$ \\
& T4 & & 0.2 & $3.05 a$ & $3.14 \mathrm{c}$ & $3.26 b$ \\
TS (Total Sulfur & T1 & AES Jak 1 & 0.1 & $3.18 a$ & $3.46 b$ & $3.97 a$ \\
ppm) & T2 & & 0.2 & $1.95 b$ & $3.25 a$ & $2.59 b$ \\
& T3 & AES Jak 2 & 0.1 & $1.95 b$ & $2.21 b$ & $2.76 a$ \\
& T4 & & 0.2 & $2.98 a$ & $3.07 a$ & $3.50 a$ \\
\hline
\end{tabular}

${ }^{1} \mathrm{~N}=3$. Means in the same column with same letters are not significantly $(P \leq 0.05)$ different with each other. T1 (AES Jak 1, 0.1\% w/w sulfite), T2 (AES Jak 1,0.2\% w/w sulfite), T3 (AES Jak 2, $0.1 \%$ w/w sulfite) and T4 (AES Jak 2, $0.2 \% \mathrm{w} / \mathrm{w}$ sulfite).

Tannin content (TC). Results of the TC values of the different treatments with storage are shown in Table 2. At 0 month, sulfite levels did not influence significantly the TC values with AES Jak 1 treatments and significant difference was noted in AES Jak 2 treatments (T3 and T4). 
Variety influenced significantly the TC values of the product either with $0.1 \%$ or $0.2 \% \mathrm{w} / \mathrm{w}$ where AES Jak 2 has higher TC values than AES Jak 1 . The difference observed could be explained by the variation of the chemical composition as well as the nature of tannin present in each variety. During the 2 months storage, sulfite levels caused a significant difference of the TC values in both varieties where at higher sulfite level, the TC values significantly decreased. The reduction of the TC values could be speculated that sulfites bind to the phenolic compounds of the product. Tannin is a phenolic compound (Murano, 2003) and Ho (1992) reported that phenolic compounds are attracting the attention of food and medical scientists, since they have antioxidative, anti-inflammatory, anti-mutagenic and anticarcinogenic activity. Rimbach, et al. (2005) as cited by Rafat et. al. (2009) stated that phenolic compounds like tannins are effective in preventing diseases because of their free radical scavenging capability and consequent antioxidant activities.

Antioxidant activity (AOA). The results of AOA (\% LP) of the 4 treatments are shown in Table 2 . The Antioxidant activity was reported as $\%$ LP which have inverse relationship. This means that the higher the \%LP, the lower the antioxidant activity. At 0 month, sulfite levels did not affect the antioxidant activity of AES Jak 1 treatments; however, for AES Jak 2 treatments, a significant difference was observed with sulfite levels. Data show that AES Jak 1 treatments have lower \%LP than AES Jak 2 treatments which means AES Jak 1 treatments have higher antioxidant activity than AES Jak 2 treatments. This can be attributed by the different nature and composition of each variety. At 2 and 4 months of storage sulfite levels and variety did not cause a significant difference on the AOA values in each variety or sufite level, respectively. During this period, the antioxidant activity of the 4 treatments was stable since no significant changes occurred.

Total reducing sugar (TRS). The results of the TRS with storage are presented in Table 2 . Results revealed that at 0 month at of storage, sulfite levels caused a significant variation on the TRS values in AES JAk 1 treatments but not with AES Jak 2 treatments. Variety on the other affected significantly the TRS values either at lower or higher level of sulfite. After 2 months of storage, sulfite levels caused a significant variation on the TRS values for both varieties. However, variety, only caused significant effect on the TRS values at higher sulfite level out not with lower level. Finally after 4 months of storage, sulfite levels caused a significant difference on the TRS values for both varieties however variety did not affect significantly the 
TRS values either with $0.1 \%$ or $0.2 \% \mathrm{w} / \mathrm{w}$ of sulfite level. Probably at this period, all of the sugar has been hydrolysed; thus, no more significant increase of TRS values was observed. It was observed that in each storage time, higher TRS values were obtained in each variety at higher sulfite level $(0.2 \% \mathrm{w} / \mathrm{w})$. These results imply that higher sulfite enhanced or intensified the hydrolyis of sucrose or the inversion of sucrose to fructose and glucose gave favorable condition. According to Rahman (2007), the rate of hydrolysis was related to changes in $\mathrm{pH}$. Lower acidity was favored for sucrose inversion. This condition is true since as observed in Table 1, at higher sulfite level in each variety, lower $\mathrm{pH}$ values were noted. This condition in a way contributed to the hydrolysis process of sucrose to produce the reducing sugars.

Total sulfur (TS). The changes of TS with time of storage are shown in Table 2. At 0 month storage, sulfite levels caused significant difference on TS values in each variety. Variety also caused a significant effect on the TRS values either at $0.1 \%$ or $0.2 \% \mathrm{w} / \mathrm{w}$ sulfite. Worth noting is that significantly higher TS values were obtained in AES Jak 2 treatments with higher sulfite level which is not true with AES Jak 1 treatments. After 2 or 4 months of storage, higher sulfite level caused significant increase of TS values than lower sulfite level. It is apparent from the results that sulfite contributed to the TS value of the product aside from the sulfur coming from the raw material. Variety did not cause a significant variation on TS values in both sulfite levels after 2 or 4 months of storage which means that the sulfur amount of the product is already stable since no significant difference was obtained.

\section{Relationship of the Parameters to DB}

Pearson correlation analysis showed that out of the 11 physico-chemical and functional parameters, $\mathrm{DB}$ was strongly correlated only with $\mathrm{pH}(\mathrm{r}=-0.701)$ and TTA $(r=-0.797)$ after four months of storage (Table 3). An inverse relationship was observed, i.e., as $\mathrm{pH}$ and TTA decreased, DB increased (Fig. 1) or vice versa. In addition, $63 \%$ and $49 \%$ of the variability of degree of browning can be explained by TTA and $\mathrm{pH}$, respectively. The functional components had weak significant correlation on the DB values of dehydrated jackfruit with storage specifically the total phenolics $(\mathrm{r}=-0.36)$ and tannin content $(\mathrm{r}=0.06)$ (Table 3$)$. Results revealed that the regression coefficient $\left(\mathrm{r}^{2}\right)$ of these compounds was very low that their influence on DB is not reliable (Fig. 2). With these findings, it can be inferred that browning in the product was not attributed by enzymes since enzymatic browning involves the oxidation of phenolic 
compounds into quinones, a brown pigmentation (Lee and Whitaker, 1995) catalyzed by polyphenol oxidase (Martinez and Whitaker, 1995 as cited by Lee etal., 2007).

Table 3. Pearson correlation of the physico-chemical parameters with DB for 4 months storage.

\begin{tabular}{cc}
\hline PARAMETERS & Degree of Browning (r ) \\
\hline $\mathrm{pH}$ & $-.701^{*}$ \\
Total Soluble Solids (TSS) & -.377 \\
Total Titratable Acidity (TTA) & $-.797^{* *}$ \\
Degree of Browning (DB) & 1.0 \\
Moisture Content (\%MC) & -.354 \\
Water Activity (A $\mathrm{A}_{\mathrm{w}}$ & .300 \\
Total Phenolics (TP) & -.355 \\
Tannin Content (TC) & .065 \\
Total Reducing Sugar (TRS) & -.152 \\
Total Sulfur (TS) & -.166 \\
Antioxidant Activity (AOA) & .102 \\
\hline
\end{tabular}

**. Correlation is significant at the 0.01 level (2-tailed);

*. Correlation is significant at the 0.05 level (2-tailed).

Probably the contribution of enzymes was just too nil that it could not significantly explain DB variation of the dehydrated jackfruit with storage. In addition, boiling and dehydration process can denature proteins and it is a known fact that enzymes are proteins. Likewise, the inclusion of sulfite as antibrowning agent can in a way destroy the enzymes present in the product; thus, their effect was not well established. Moreover, sulfites react with PPO itself, thus irreversibly inhibiting PPO by modification of the protein structure (Lambrecht, 1995).
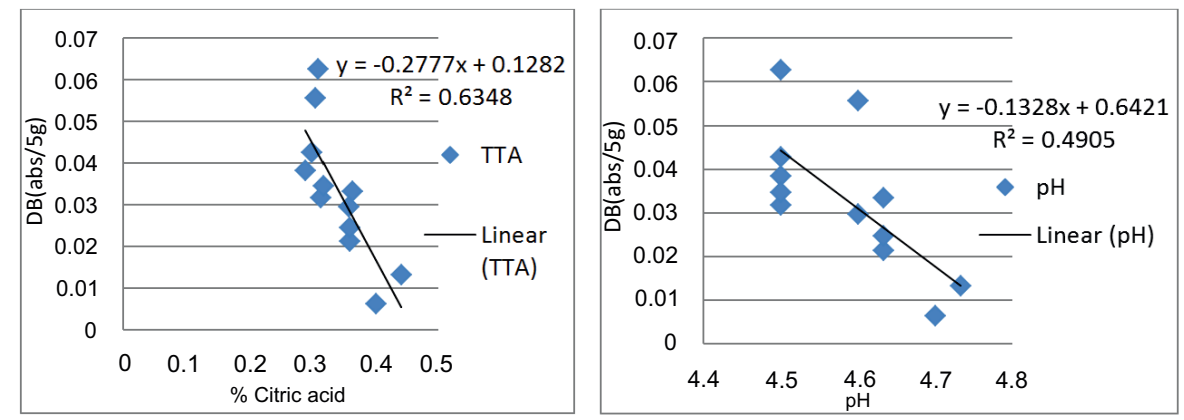

Figure 1. Relationship of total titratable acidity and $\mathrm{pH}$ to degree of browning on dehydrated jackfruit stored for four months at ambient temperature. 
Sulfite concentration did not affect significantly the TTA and $\mathrm{pH}$ of the product with time be it $0.1 \%$ or $0.2 \% \mathrm{w} / \mathrm{w}$. Therefore, these amounts could be used in the formulation. Sodium sulphite is a potent inhibitor of polyphenol oxidases and peroxidases and was used widely to inhibit enzymatic and non enzymatic browning in fruits and vegetables (Wu et al.,1999; Molnar-Perl \& Friedman, 1990 as cited in Singh et al., 2002).

Non-enzymatic browning (NEB) reaction is strongly dependent on concentration, ratio and chemical nature of reactants, temperature, time of heating, water content and pH (Buera et al, 1987 as cited by Acevedo et al., 2008). Results revealed that variety caused significant variation to the $\mathrm{pH}$ and TTA with time, thus variety should be considered in processing a dehydrated jackfruit to inhibit browning in the product. The relationship of $\mathrm{pH}$ and TTA to DB in each variety is shown in Fig. 4. The Fig. shows that $\mathrm{pH}$ and TTA were inversely related with DB for AES Jak 1 . This means that as $\mathrm{pH}$ and TTA increase, DB decreases.

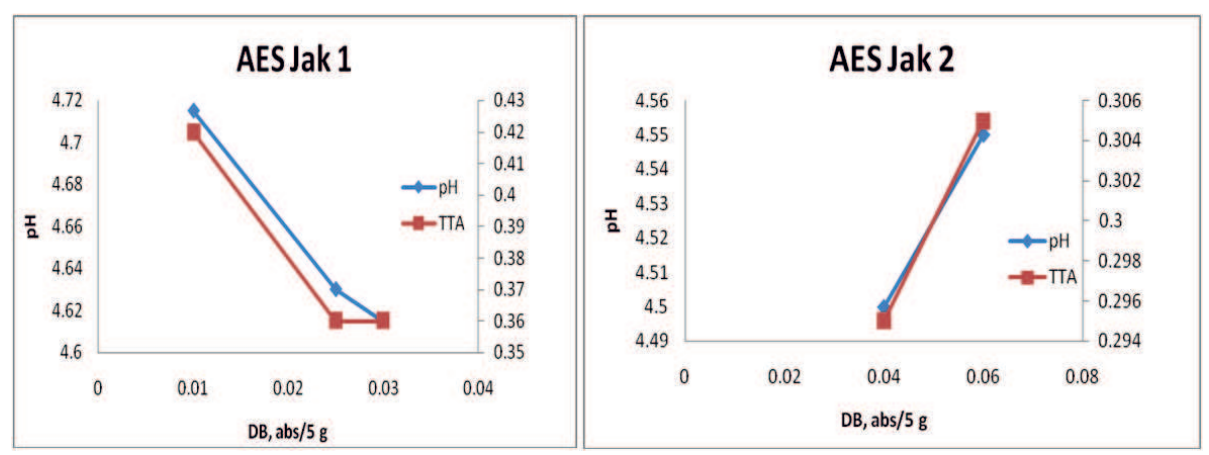

Figure 4. Comparison of the relationship of total titratable acidity and $\mathrm{pH}$ to the degree of browning on dehydrated jackfruit using AES Jak 1 and AES Jak 2 stored for four months at ambient temperature.

On the other hand, a direct relationship was observed for AES Jak 2 variety which means that as $\mathrm{pH}$ and TTA increase, DB also increases. Therefore, to control browning development of dehydrated jackfruit during storage, $\mathrm{pH}$ and TTA can be used as a method of control. Likewise, the use of a suitable variety, specifically AES Jak 1 variety, and the application of sodium metabisulfite at 0.1 to $0.2 \% \mathrm{w} / \mathrm{w}$ as one of the preservatives can aslo be done.

\section{CONCLUSION AND RECOMMENDATIONS}

Based on the results of the study, it can be concluded that use of sulfite 


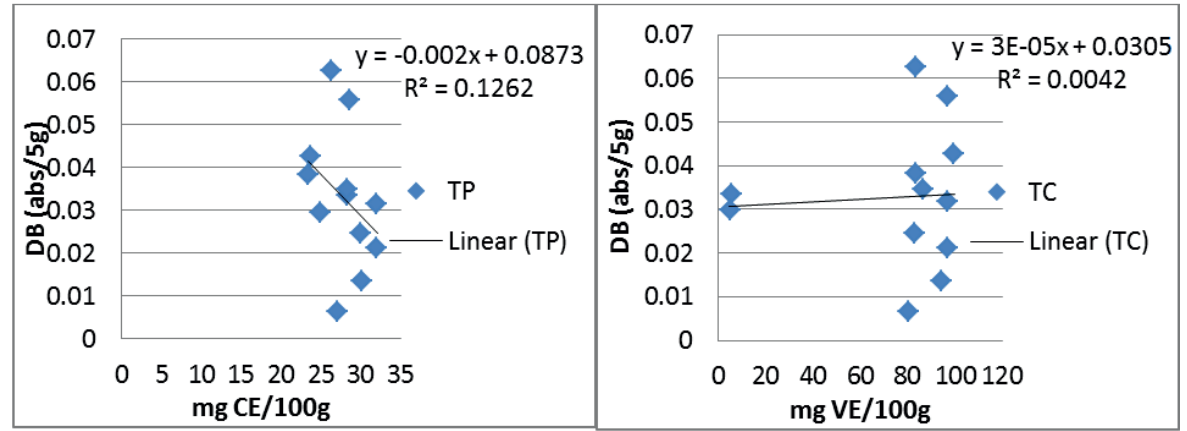

Figure 2. Relationship of total phenolics and tannin content to degree of browning on dehydrated jackfruit stored for four months at ambient temperature.

Therefore, the browning in the dehydrated jackfruit may be attributed more to the non-enzymatic browning (maillard, caramelization and ascorbic acid oxidation). Maillard reaction involves compounds with amino groups and reducing sugars present in foods. Caramelization involves degradation of sugars. Ascorbic acid plays a central role in browning of citrus juices and concentrates (Eskin, 1990). From the three non-enzymatic browning, browning due to ascorbic acid could be eliminated from the choices since the dehydrated product is considered as intermediate food. For maillard the two reactants were present since jackfruit also contains small amount of proteins and reducing sugars which can be obtained from the jackfruit and the sucrose used in processing the product. TRS and TSS had a weak correlation (Table 3) with DB; thus, their influence to DB values was insignificant or not established (Fig. 3).
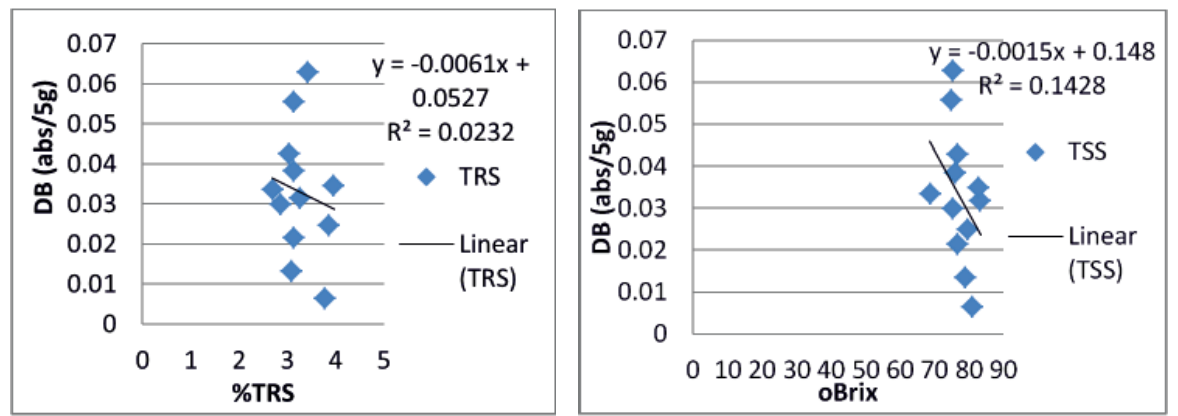

Figure 3. Relationship of total reducing sugars and total soluble solids to degree of browning on dehydrated jackfruit stored for four months at ambient temperature. 
either 0.1 or $0.2 \%$ (w/w) can minimize browning in the formulation of the product. AES Jak 1 is the more suitable variety for dehydrated jackfruit since it is less sensitive to browning reaction than AES Jak 2. Browning in dehydrated jackfruit can be inhibited by $\mathrm{pH}$ and TTA. Correlation shows that as $\mathrm{pH}$ and TTA increase, DB decreases.

It is therefore recommended that microbiological and sensory evaluation of the different treatments should be done to see the total picture of the effect of variety and sulfite levels on browning of stored dehydrated jackfruit.

\section{ACKNOWLEDGMENT}

We would like to thank VSU, DOST, PCAARRD, CHED, DA-BAR and NRCP for the financial support provided to the researchers.

\section{REFERENCES}

ACEVEDO, N.C., SHEBOR, C. and BUERA, P. 2008. Non-enzymatic browning kinetics analysed through water-solids interactions and water mobility in dehydrated potato. Food Chemistry 108:900-906.

AHMED, M., AKTER, M.S. and EUN, J.B. 2010. Peeling, drying temperatures, and sulphite-treatment affect physicochemical properties \& nutritional quality of sweet potato flour. Food Chemistry 121:112-118.

AJANDOUZ, E.H. and PUIGSERVER, A. 1999. Nonenzymatic browning reaction of essential amino acids: effect of $\mathrm{pH}$ on caramelization and maillard reaction kinetics. Journal of Agricultural Food Chemistry 47:1786-1793.

AOAC. 1980. Official Methods of Analysis of the Association of Official Analytical Chemists. $13^{\text {th }}$ ed. W. Horwitz (ed) Washington D.C., USA.

BROWN, AMY. 2005. Understanding Food: Principles and Preparation. $2^{\text {nd }}$ edition.Wadsworth, Thomson Learning Inc., Canada. Singapore.

CARBONARA, M, and MATTERA, M. 2001.Polyphenoloxidase activity and polyphenol levels in organically and conventionally grown peach (Prunuspersica L.,cv.Reginabianca) and pear (Pyruscommunis L., cv. Williams). Food Chemistry, 72:419-424. 
CERNISEV, S. 2010. Effects of conventional and multistage drying processing on non-enzymatic browning in tomato. Journal of Food Engineering 96:114-118.

CORONEL, R.E. 1983. Promising Fruits of the Philippines. Published by the College of Agriculture, U.P. Los Baños, Laguna Philippines.

CRUZ, R.T. DELA. 2002. A Second Look at Jackfruit. BAR Chronicle, a monthly publication. Vol 3 No. 6 dated March 16-31, 2002. http://www.bar.gov.ph/barchronicle/2002/mar02_16-31_a second.asp (retrieved 11-20-09).

DE LEON , S.V. 1987. Effects of Pre-drying treatments on the Physico-chemical, Nutritive and Organoleptic Qualities of Package Dehydrated Tropical Fruits. V. Jackfruit. Unpublished Research Terminal Report. Quezon City, Philippines, U.P. Diliman.

DIAMANTE, L.M. 2005. Development of Food products from Jackfruit. Unpublished Research Proposal. OVPRE, Visayas State University, Visca, Baybay City, Leyte.

DING, C., CHACHIN, K., UEDA, Y. and WANG, C.Y. 2002. Inhibition of loquat enzymatic browning by sulfhydryl compounds. Food Chemistry 76:213218.

ESKIN, N.A.M. 1990. Biochemistry of Foods. $2^{\text {nd }}$ ed. Academic Press, Inc. New York. $557 \mathrm{pp}$.

FERNANDES, F.A.N., RODRIGUES, S., GASPARETO, O.C.P. and OLIVEIRA, E.L. 2006. Optimization of osmotic dehydration of papaya followed by airdrying. Food Research International 39:492-498.

FERNANDEZ, L.M.F. 2005. Effect of temperature on the drying characteristics of sweetened jackfruit (Artocarpus heterophyllus Lam.) and sensory qualities of its dried product. Unpublished BSFT Thesis. LSU, Visca, Baybay, Leyte.

GOLOSINO, G.M. 2004. Effect of level of citric acid on the drying characteristics and sensory qualities of dehydrated sweetened jackfruit (Artocarpus heterophyllus Lam.) with added ascorbic acid. Unpublished BSFT Thesis. LSU, Visca, Baybay, Leyte. 
Browning of dehydrated jackfruit pulp

HO, C.T. 1992. Phenolic compounds in food. In:Ho et al. editors. Phenolic compounds in food and their effect on health. USA: Library Congress Cataloging in Publication Data. P. 2-7.

JAY, J. M. 2000. Modern Food Microbiology. $6^{\text {th }}$ ed. Aspen Publishing, Inc. Maryland, USA.

JEONG, H.L., JIN, W.J., KWANG, D.M. and KEE, J.P. 2008. Effects of antibrowning agents on polyphenoloxidase activity and total phenolics as related to browning of fresh-cut "fuji" apple. ASEAN Food Journal 15(1):79-87.

JOHNTON, B. and BAHR, L.S. Eds. 1995. Collier's Encyclopedia.Volume 10. Collier's Publishing Company, USA..

LAMBRECHT, H.S. 1995. Sulfite substitutes for the prevention of enzymatic browning in foods. In: Lee C.Y and Whitaker, J.R. (Eds.) Enzymatic Browning and its Prevention. American Chemical Society, Washington D.C. pp 313-323.

LAPICEROS, J.B. 2007. Effects of chilling and freezing temperatures and duration on the sensory qualities and storage stability of dehydrated sweetened jackfruit. Unpublished BSFT Thesis. LSU, Visca, Baybay, Leyte.

LEE, M.Y., LEE, M.K. and PARK, I. 2007. Inhibitory effect of onion on polyphenol oxidase and enzymatic browning of taro (Colocasia antiquorum var. esculenta). Food Chemistry 105:528-532.

LEE, C.Y. and WHITAKER, J.R. 1995. Recent Advances in chemistry of enzymatic browning. In:Lee, C.Y.and Whitaker, J.R. (Eds). Enzymatic Browning and its Prevention. Washington, DC, USA: American Chemical Society.pp2-7.

LEONG, L.P. and SHUI, G. 2002. An investigation of antioxidant capacity of fruits in Singapore markets". Food Chemistry 76: 69-75.

MAHAYOTHEE, B., UDOMKUN, P., NAGLE, M., HAEWSUNGCHAROEN, M., JANJAI, S. and MUELLER, J. 2009. Effects of pretreatments on colour alterations of litchi during drying and storage. European Food Research and Technology 229:329-337. 
MARSHALL, M.R., KIM, J. and WEI, C.I. 2000.Enzymatic browning in fruits, vegetables and Seafoods.In FAO. http://www.fao.org/ag/Ags/agsi/ ENZYMEFINAL/enzymatic browning.html.retrieved: Nov. 26,2009.

MILLER, G.L. 1972.Use of dinitrosalicylic acid reagent for determination of reducing sugars. Anal. Chem.31, 426-428.

MURANO, P.S. 2003.Understanding Food Science and Technology. Wadsworth, Thomson Learning Inc., Canada. pp.449

NICOLAS, J.J., RICHARD-FORGET, F.C., GOUPY, P.M, AMIOT, M.J. and AUBERT, S.Y. 1994. Enzymatic browning reactions in apple and apple products. Critical Reveal Food Science and Nutrition, 34:109-157.

PESQUERA, M.L.M. 2002. Effect of sugar levels on the drying rates and sensory qualities of dehydrated sweetened jackfruit. Unpublished BSFT Thesis, LSU, Visca, Baybay, Leyte.

QUINDE-AXTELL, Z., POWERS, J. and BAIK, B.K. 2006.Retardation of discoloration in barley flour gel and dough. Cereal Chemistry. 83(4):385390 .

RAFAT, A., PHILIP, K. and MUNIANDY, S. 2009. Antioxidant potential and content of phenolic compounds in ethanolic extracts of selected parts of Andrographispaniculata. Journal of Medicinal Plants Research 4(3):197202.

RAHMAN, M.S. 2007. pH in Food Preservation. In RAHMAN, M.S. (ed). Handbook of Food Preservation. $2^{\text {nd }}$ ed. CRC Press, Taylor and Francis Group, New York. pp: 287-312.

RAHMAN, M.S. and LABUZA, T.P. 2007. Water Activity and Food Preservation. In RAHMAN, M.S. (ed). Handbook of food preservation. $2^{\text {nd }}$ ed. CRC Press, Taylor and Francis Group, New York. pp. 447-476

SANDHU, S.S., KEIM, W.F., HODGES, H.F. and NYQUIST,W.E. 1974. Inheritance of protein and sulfur content in seeds of chickpeas. Crop Science, 14:649-651. 
Browning of dehydrated jackfruit pulp

SANSAN, N.M. 2004. Effects of sodium metabisulfite level and storage time on the sensory qualities of dehydrated jackfruit flavored Bocarillo. Unpublished BSFT Undergraduate Thesis. Visayas State University, Visca, Baybay City, Leyte.

SAXENA, A., BAWA, A.S. and RAJU, P.S. 2009.Optimization of a multitarget preservation technique for jackfruit (Artocarpus heterophyllus L.). Journal of Food Engineering 91(1):18-28.

SHAMSUDIN, R., LING, C.S., LING, C.N., MUDA, N. and HASSAN, O. 2009. Chemical compositions of the jackfruit juice (Artocarpus) cultivar J33 during storage. Journal of Applied Sciences 9 (17):3202-3204.

SINGH, R.H., NIE, X., SINGH, M., COFFIN, R. and DUPLESSIS, P. 2002. Sodium sulphite inhibition of potato and cherry polyphenolics in nucleic acid extraction for virus detection by RT-PCR. Journal of Virological Methods. 99:123-131.

SUN B, RICARDO-DA-SILVA, J.M. and SPRANGER, I. 1998. Critical factors of vanillin assay for catechin and proanthocyanidins. Journal of Agriculture and Food Chemistry 46 (10): 4267-427.

TAMBIS, J.G. 2006. Effect of drying temperature on the drying characteristics and sensory qualities of sweetened jackfruit (Artocarpus heterophyllus, L.) with non-sulfite preservatives. Unpublished BSFT Thesis. LSU, Visca, Baybay, Leyte.

UMNAT, S. 2010. Optimization of embic fruit (Phyllanthus emblica L.) processing methods for maximum retention of functional properties. Unpublished PhD Dissertation, College, Laguna, Philippines: University of the Philippines.

VELIOGLU, Y.S., MAZZA, G., GAO, L. and OOMAH, B.D. 1998. Antioxidant activity and total phenolics in selected fruits, vegetables and grain products. Journal of Agriculture and Food Chemistry 46:41134117. 